\title{
Ovarian function in the captive black mastiff bat, Molossus ater
}

\author{
J. J. Rasweiler IV \\ Department of Obstetrics and Gynecology, Cornell University Medical College, \\ 515 East 71st Street, New York, NY 10021, U.S.A.
}

\begin{abstract}
Summary. In nearly all animals from a laboratory breeding colony that were examined $(85 / 86)$ the right ovary was significantly larger than the left. Although primordial follicles were present in both ovaries, Graafian follicles and CL were noted only in the right ovary. The left ovary usually had a much less prominent intraovarian vascular supply, and it is suggested that this may play a central role in limiting the ability of follicles to grow on that side. Many of the bats examined very soon after the introduction of stud males had well-developed CL, sometimes of 2-3 different ages, and uteri that had probably been subjected to stimulation by luteal hormones. Such observations made on females that had been housed with a stud male only for $24 \mathrm{~h}$ indicate that the black mastiff bat is a spontaneous ovulator with a functional luteal phase. It was common to observe an extended period after the introduction of a stud male during which spermatozoa were present in the vaginal smears from a female almost every day. Most of the ovulations that resulted in pregnancies appear to have occurred during this period. Of the 72 bats with $C L, 11$ possessed 2 or more $C L$ of the same age, indicating that multiple ovulations can sometimes take place. The right ovaries of all females examined during advanced pregnancy had non-atretic, vesicular or Graafian follicles in addition to the CL of pregnancy.
\end{abstract}

Keywords: black mastiff bat; ovarian asymmetry; ovulation

\section{Introduction}

The black mastiff bat (Molossus ater) is an insectivorous, colonial species which is common in many tropical areas of the New World. Recently, efforts have been successfully undertaken to breed this bat in captivity (Rasweiler, 1987), so that it could be utilized as a model in investigations focussing upon the morphogenesis of the chorioallantoic placenta. The present paper deals with some of the observations made on ovarian function in the captive animals, most of which were killed primarily for the placental studies.

\section{Materials and Methods}

Animal procurement. All of the bats utilized in this study were captured with mist nets as they left their roosts in buildings in central Trinidad, West Indies, to forage. Collections were made during early July, mid-August and late November.

Animal care and management. The bats were maintained in a laboratory colony established at Cornell University Medical College according to the procedures described previously (Rasweiler, 1987). The colony was kept in a warm room $\left(29-31{ }^{\circ} \mathrm{C}\right)$ with the lights on from 04:00-16:00 h. The females were housed in sexually-segregated groups of 8-15 animals per cage from the time of their arrival in New York. Between 2 and 7 months later a single male was introduced into each of these cages. Vaginal smears were then obtained from the females each morning and checked for spermatozoa. Many of the females housed with males for prolonged periods exhibited a period of $10-50$ days during which spermatozoa were present in the vaginal smears almost every day. Spermatozoa were also observed sporadically in the smears before and after this interval (Rasweiler, 1987). It was suspected that ovulation occurred at 
some time during the period when spermatozoa were present for many days in succession. In an effort to test this hypothesis and to obtain reproductive tracts in different stages of pregnancy, females were killed at various times after the first appearance of spermatozoa in the vaginal smears for 3 days or more in succession. To investigate further the influence of the male upon ovarian function, one group of 8 females was killed after having been sexually isolated for 7 months. During the last $24 \mathrm{~h}$ these animals were housed with a stud male to collect information on their sexual receptivity and sperm transport in the female tract. A single vaginal smear was obtained from each of these females immediately before death. All of the subjects of this study were killed between January and June of the year after capture.

Histological procedures. Females were killed between 09:00 and 12:00 $\mathrm{h}$ and their reproductive tracts were removed for histological examination. When large enough to be easily removed from the tracts, conceptuses were fixed separately, measured and weighed. The tracts were fixed in Zenker's fluid for $10-12 \mathrm{~h}$, washed overnight in running tap water and processed through graded ethyl alcohols, cedar wood oil and Histosol (National Diagnostics, Inc., Somerville, NJ, U.S.A.) to paraffin wax. Most of the tracts were then serially sectioned at $6 \mu \mathrm{m}$. Because of their size the only exceptions were the tracts obtained late in pregnancy. In these cases usually just the ovaries and that portion of the uterus containing the chorioallantoic placenta were serially sectioned. The histological sections were stained with haematoxylin and eosin, Masson's trichrome procedure, or the periodic acid-Schiff (PAS) technique and haematoxylin. Some sections from each tract were incubated for $1 \mathrm{~h}$ at $37^{\circ} \mathrm{C}$ in $0 \cdot 1 \% \alpha$-amylase (1,4- $\alpha$-D-glucanglucano-hydrolase; Sigma Chemical Company, St Louis, MO, U.S.A.) dissolved in a $0.02 \mathrm{~m}$-phosphate buffer (pH 6) to remove any glycogen before being stained by the PAS procedure. Parallel sections were incubated under similar conditions in the buffer alone and then stained. The glycogen-hydrolysing ability of the enzyme solution was confirmed by tests on sections of liver and skeletal muscle.

Reproductive condition of laboratory-maintained bats. Female black mastiff bats in the following reproductive states were examined in this study: non-pregnant with no large follicles or corpora lutea (10 bats); non-pregnant with healthy, large vesicular or Graafian follicles (12 bats); non-pregnant with recently formed CL (17 bats); non-pregnant carrying a newly-released secondary oocyte ( 1 bat); pregnant with a tubal embryo ( 1 bat); pregnant with uterine conceptuses varying from unimplanted embryos to near-term fetuses ( 45 bats).

\section{Results}

\section{Reproductive seasonality in the wild bat population}

Some of the observations made on black mastiff bats in this study may reflect seasonal breeding patterns in the wild population and the time of year at which the experiments were carried out. It
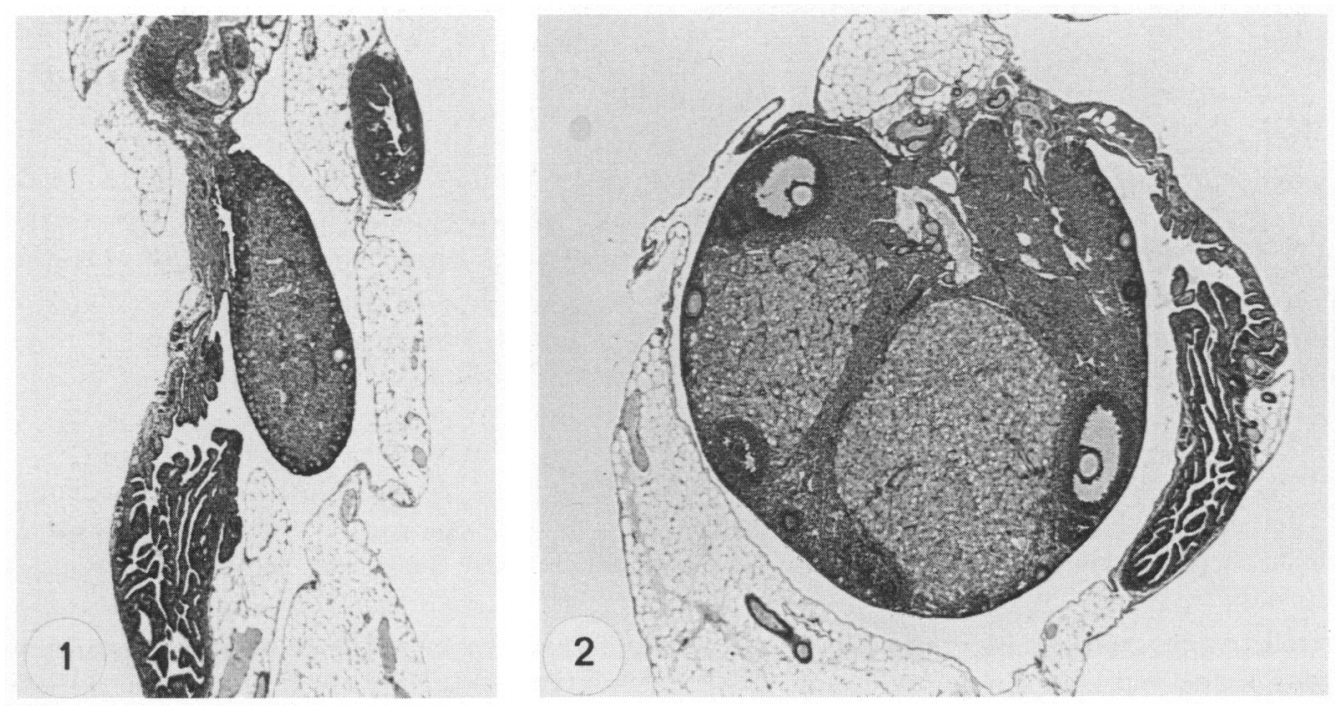

Figs 1 \& 2. Sections through the left (Fig. 1) and right (Fig. 2) ovaries from a non-pregnant bat (No. 52B) killed 5 days after the introduction of a stud male. Note the marked size difference between the two ovaries. Two CL of different ages are evident in the right ovary (see also Figs $9 \& 10$ ). Both ovaries are surrounded by bursae which have openings (not shown) to the peritoneal cavity near the mouth of each oviduct. PAS-haematoxylin, $\times 31$. 

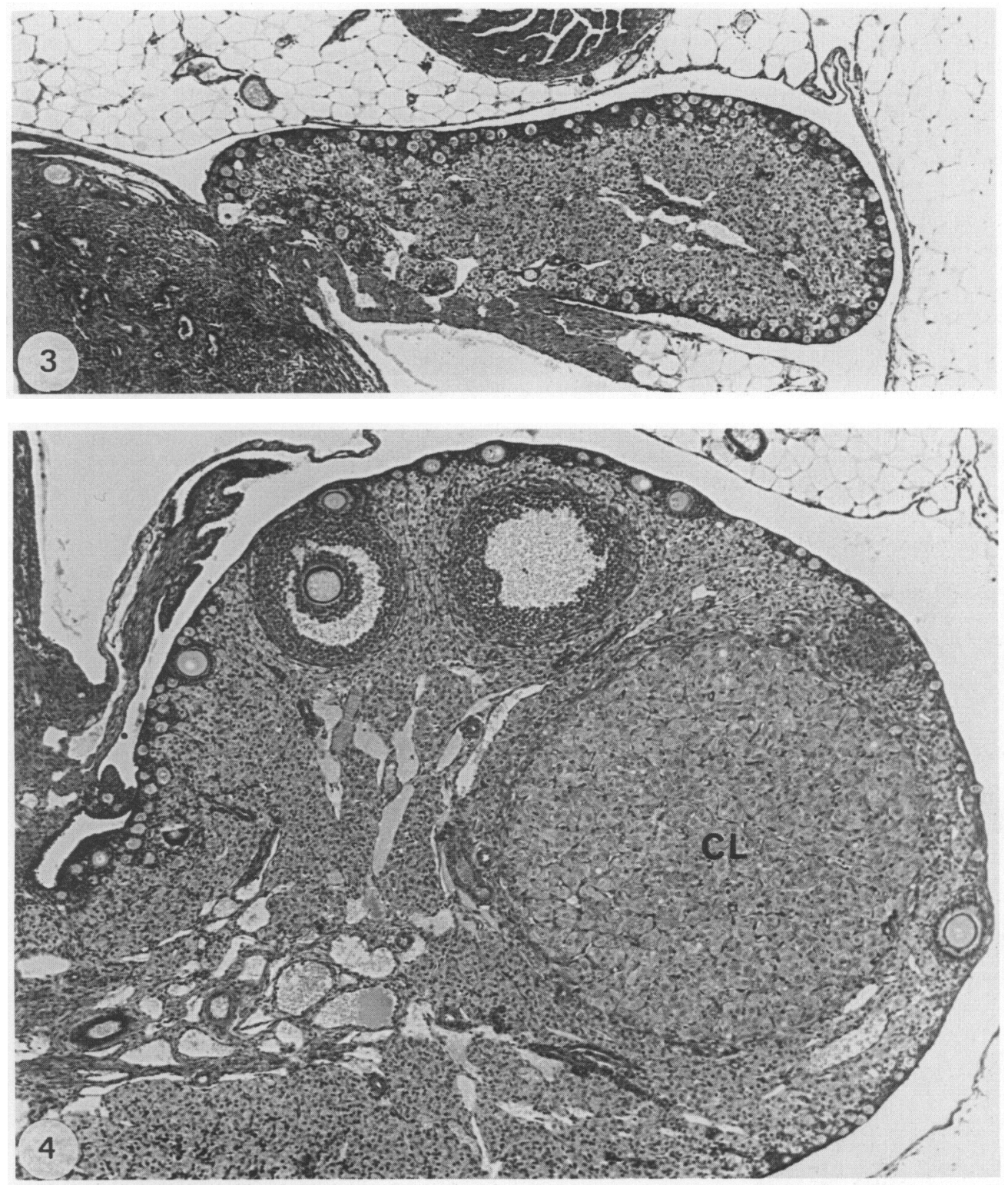

Figs $3 \& 4$. Medium-power view of the left (Fig. 3) and right (Fig. 4) ovaries from Bat 59B. Numerous primordial follicles are present in the cortices of both ovaries, but no growing follicles are evident in the section of left ovary shown. Both ovaries also contain abundant interstitial gland tissue. Note that the intraovarian vascular supply of the right ovary is much more prominent than that of the left ovary. PAS-haematoxylin, $\times 80$.

therefore seems important to present the following preliminary evidence that reproductive synchronization does occur in the species. Some of the females taken in July (25/215) and August (10/118) were pregnant and aborted or gave birth between capture and mid-September. This may underestimate the proportion of pregnant bats in the wild population at those times because the precise reproductive condition of all the recently captured females could not be determined. In contrast, none of the females $(\mathrm{N}=180)$ captured in November aborted or delivered young after being brought into captivity. 

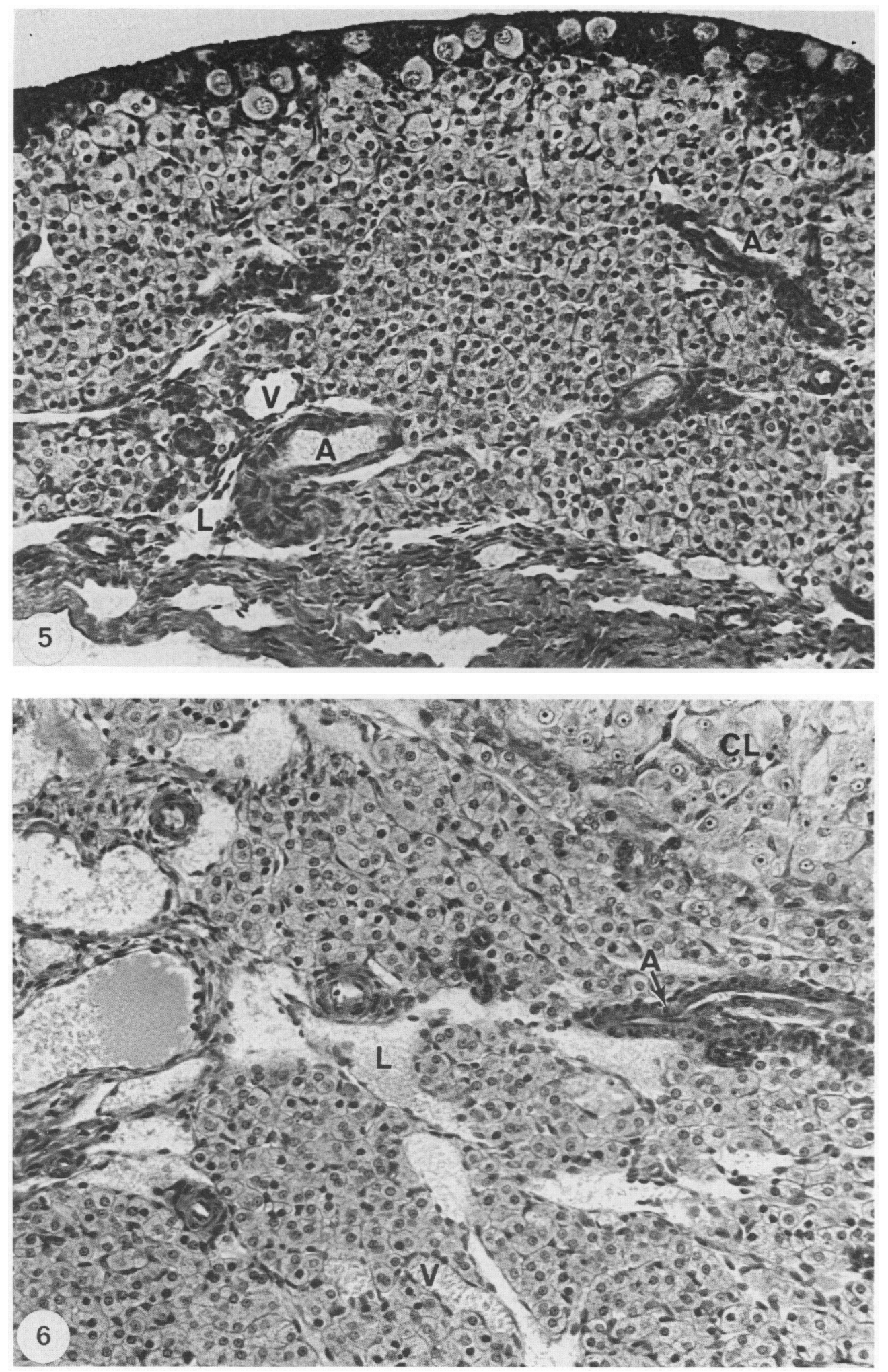


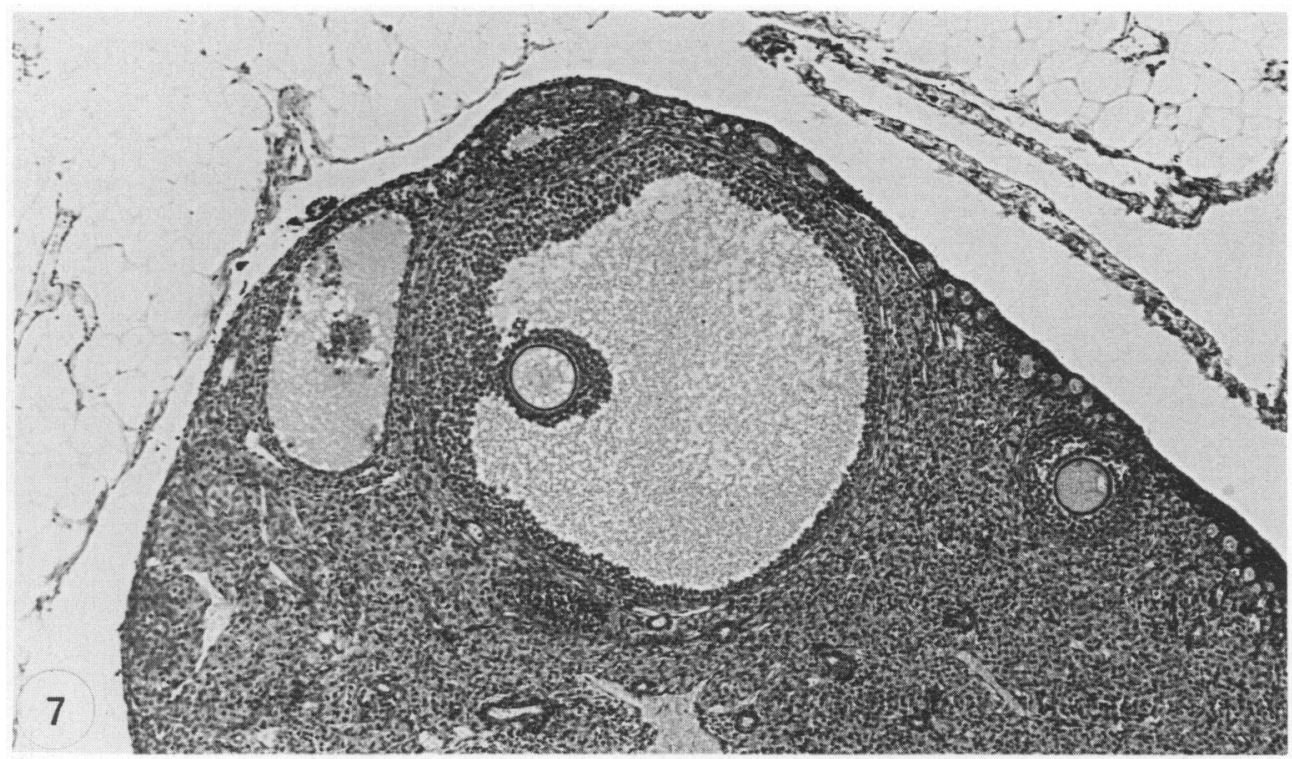

Fig. 7. Section of right ovary from Bat 54B showing the Graafian follicle. This contained an oocyte at the germinal vesicle stage. This animal was killed 5 days after the introduction of the stud male and 4 days after the first appearance of spermatozoa in her vaginal smears. PAShaematoxylin, $\times 80$.

\section{Differences between right and left ovaries}

In nearly all of the female black mastiff bats differences were noted between the right and left ovaries. With the exception of one animal, the right ovary was always larger (Figs 1-4). Both ovaries contained primordial follicles, but it was not readily apparent whether the total number of these follicles differed consistently between the two sides in all animals, because the primordial follicles tended to be more widely dispersed along the cortical periphery in the larger right ovary than in the left. Follicular development beyond the primordial stage was generally retarded in the left ovary. In most bats $(81 / 86)$ the largest follicles seen on the left side were only primary follicles with enlarged oocytes or secondary (non-antral) follicles with no more than 5-6 layers of granulosa cells. A few vesicular follicles were noted in the left ovary in 4 animals, but these were all atretic. Healthy Graafian follicles and CL were observed only in the right ovary (Figs 2, 4, 7, 8, 13, 14). In pregnant animals the conceptuses were always in the right oviduct or uterine horn. Both ovaries contained an abundance of interstitial gland tissue (Figs 3-6) in all specimens examined, but the total volume of this component was generally much less in the smaller, left ovary. The right ovary also usually had a much more prominent intraovarian vascular supply than the left (Figs 3-6), even in those animals lacking large vesicular follicles or CL. Typically, larger arterial and venous vessels were evident in the medulla of the right ovary than in the left. In turn these ramified into a greater number of arterioles and venules in the more extensive cortex of the right ovary.

In one exceptional animal the ovaries were equally sized and similar with respect to their vascularity and content of interstitial gland tissue. This bat was also unusual in having relatively large, atretic vesicular follicles in both ovaries.

Figs 5 \& 6. Higher power views of the ovarian vascular supply in the left (Fig. 5) and right (Fig. 6) ovaries from Bat 59B. The arterioles (A), venules (V) and lymphatics (L) are surrounded by abundant interstitial gland tissue. Primordial follicles may be seen in the superficial cortex of the left ovary. PAS-haematoxylin, $\times 234$. 


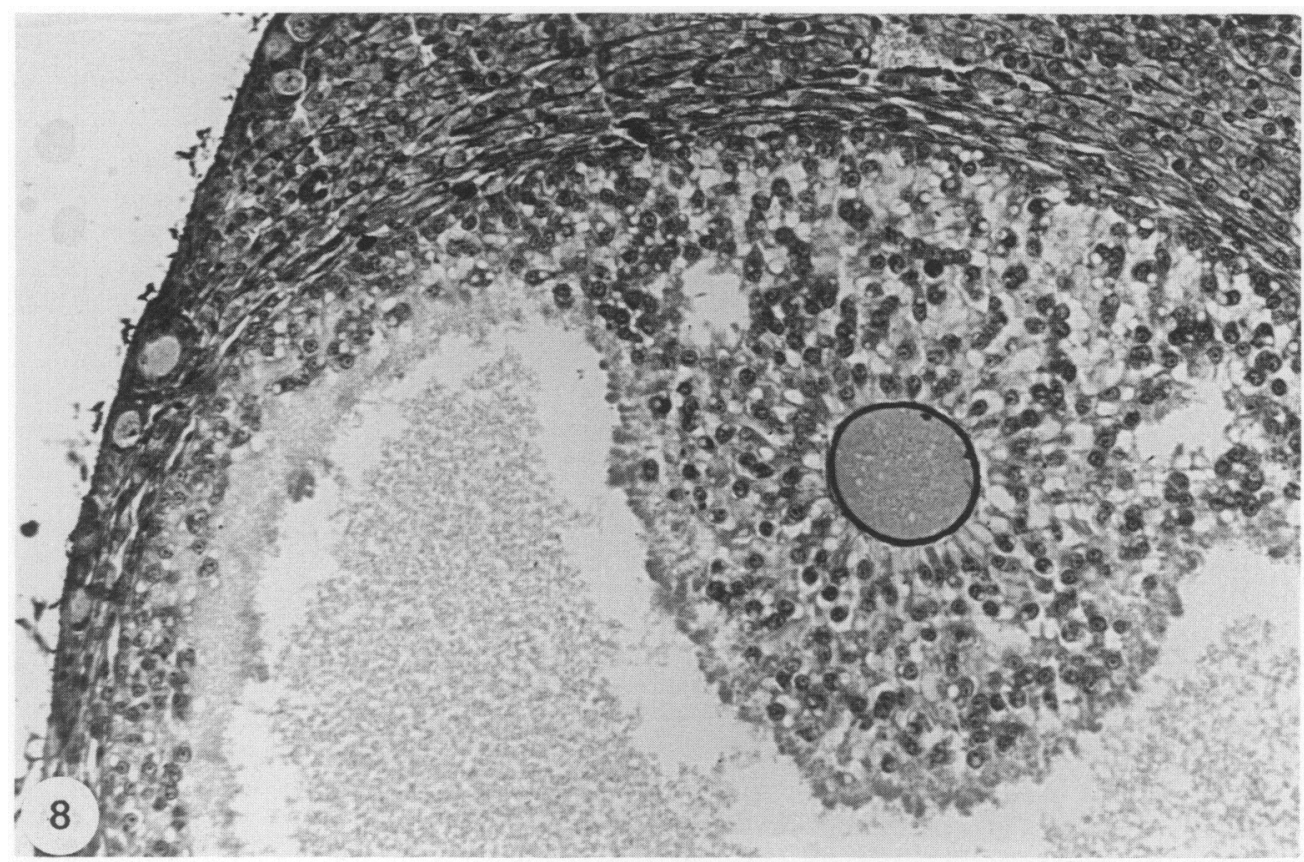

Fig. 8. Section of right ovary from Bat 60 showing the Graafian follicle. This animal was killed after exhibiting sperm-positive smears for 8 successive days. Expansion of the cumulus oophorus is evident around the oocyte which had completed the first meiotic division. PAS haematoxylin, $\times 202$.

\section{Luteal cytology}

The nucleoli of the lutein cells varied considerably in size and provided a particularly useful means of histologically assessing the relative ages of many CL. The nucleoli of the granulosa cells of recently ruptured follicles enlarged during the luteinization process and were unusually

Table 1. Reproductive condition of black mastiff bats sexually isolated for 7 months in captivity and then housed with a male for $24 \mathrm{~h}$

\begin{tabular}{|c|c|c|c|c|}
\hline \multirow[b]{2}{*}{$\begin{array}{l}\text { Animal } \\
\text { no. }\end{array}$} & \multirow[b]{2}{*}{$\begin{array}{l}\text { Spermatozoa } \\
\text { in tract }\end{array}$} & \multicolumn{2}{|c|}{ No. of $C L^{*}$} & \multirow[b]{2}{*}{ Endometrial condition } \\
\hline & & $\begin{array}{l}\text { Most } \\
\text { recent }\end{array}$ & Older & \\
\hline $44 \mathrm{C}$ & - & 1 & 2 & Stimulated, early luteal phase \\
\hline $45 \mathrm{C}$ & - & 1 & 2 & $\begin{array}{l}\text { Necrosis and sloughing of decidua } \\
\text { (both horns) }\end{array}$ \\
\hline $46 \mathrm{C}$ & $+\dagger$ & $2 \ddagger$ & $4 \S$ & Decidual reaction (both horns) \\
\hline $47 \mathrm{C}$ & - & - & 2 & Involuted \\
\hline $48 \mathrm{C}$ & - & 1 & $4 \S$ & Stimulated, luteal phase \\
\hline $49 \mathrm{C}$ & $+\dagger$ & 1 & 2 & Stimulated, luteal phase \\
\hline $50 \mathrm{C}$ & $+\dagger$ & $2 \ddagger$ & 2 & $\begin{array}{l}\text { Decidual reaction (both horns); } \\
\text { decidual necrosis and sloughing in } \\
\text { left horn }\end{array}$ \\
\hline $51 \mathrm{C}$ & - & - & 2 & Involuted \\
\hline
\end{tabular}

*CL in each bat were of different ages unless otherwise noted. † Spermatozoa in vagina and cervix only.

$\$ C L$ were of the same age.

$\S$ Bat had 2 pairs of older CL, each pair of a different age. 
prominent in the lutein cells of new $\mathrm{CL}$ (Fig. 9) in bats $(\mathrm{N}=26)$ carrying early uterine conceptuses (i.e. unimplanted embryos through fetuses of $5.8 \mathrm{~mm}$ crown-rump length). The nucleoli of these cells were smaller, but still prominent, in females $(\mathrm{N}=6)$ bearing fetuses of $6 \cdot 1-7 \cdot 2 \mathrm{~mm}$ crownrump length. Such large nucleoli were not seen in the $C L$ of bats $(N=17)$ carrying fetuses of 9.7-34.8 mm crown-rump length (Fig. 11). Fetuses at the upper end of this range were near term. Medium to large nucleoli were also evident in the lutein cells of the most recently formed CL in many of the non-pregnant females examined, including 5 of the females which had only been housed with a male for $24 \mathrm{~h}$ (Table 1). Two of the latter animals had not yet mated. Such large nucleoli were not seen in older, regressing CL (Fig. 10). The oldest regressing CL also generally had much smaller lutein cells.
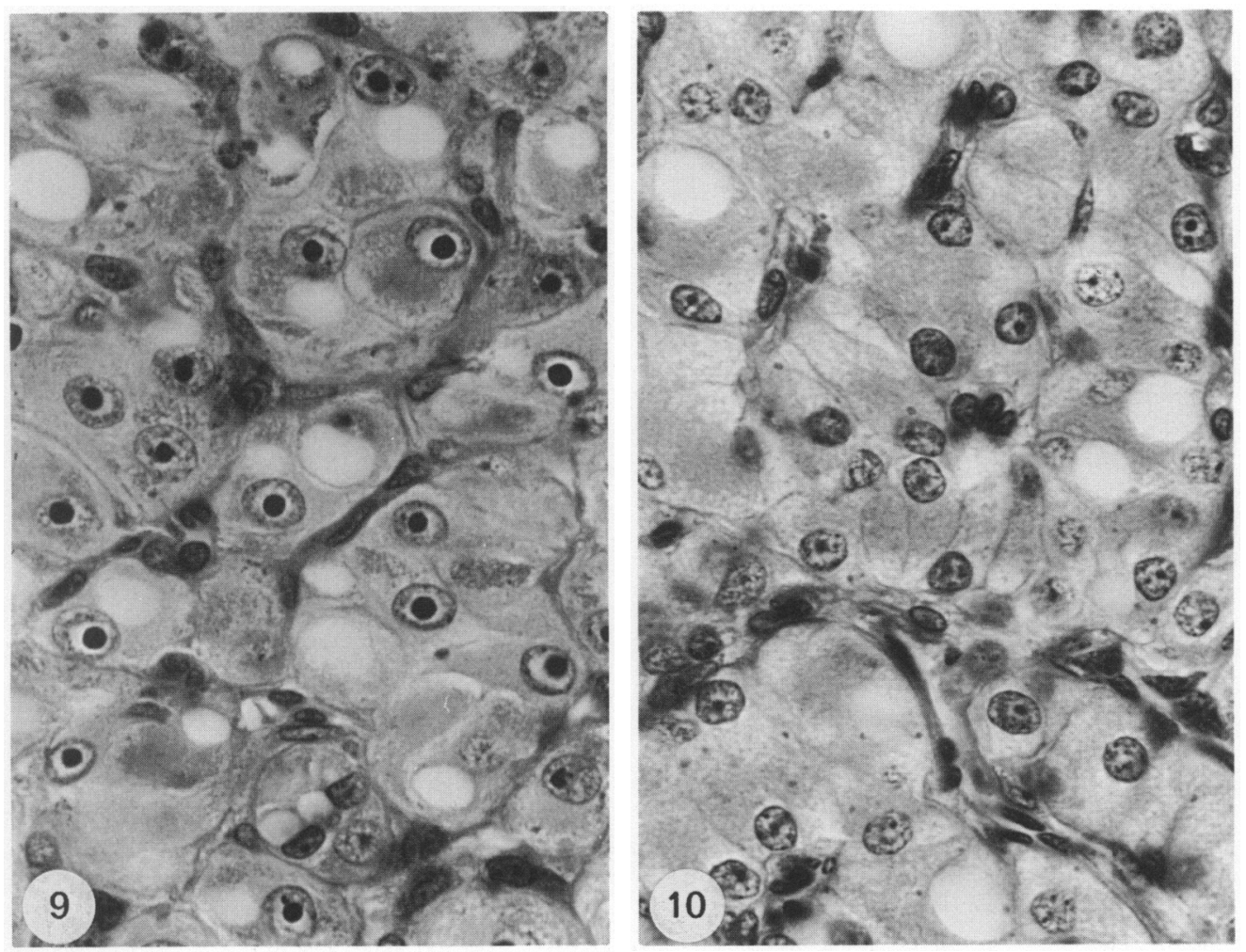

Figs $9 \&$ 10. Sections of the new (Fig. 9) and older (Fig. 10) CL found in the right ovary of a non-pregnant bat (No. 52B). Note the unusually prominent nucleoli in the lutein cells of the new CL. Many of the lutein cells in both CL contain large vacuoles. PAS-haematoxylin, $\times 642$.

\section{Spontaneous ovulation}

Studies of the reproductive tracts from females which had been sexually isolated for 7 months and then housed with a male only for $24 \mathrm{~h}$ provided evidence that the black mastiff bat is a spontaneous ovulator (Table 1). When killed on 19 June each of these females had CL of 2-3 different ages, all of which must have been formed before the introduction of the male. In most of these females (6/8) 1-2 CL appeared relatively new, and their uteri seemed to have been stimulated by luteal hormones. In several bats decidual reactions had occurred, despite the fact that the endometria had not been stimulated by an implanting embryo or experimental traumatization 


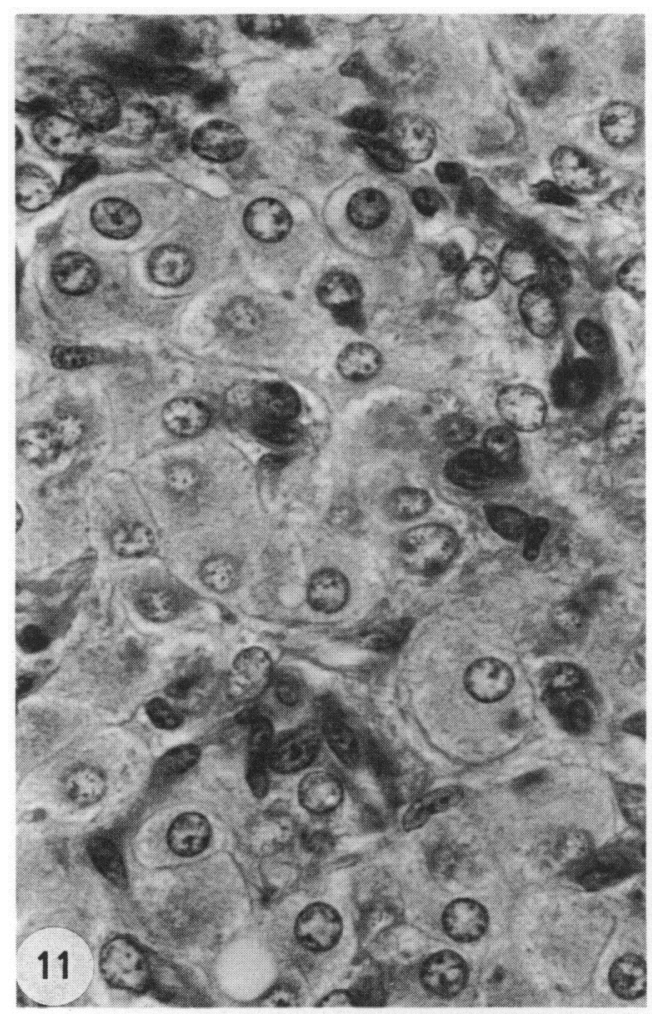

Fig. 11. High-power view of the CL of pregnancy shown in Fig. 14. The lutein cells are still intact, but many appear smaller and less vacuolated than those present in newly formed $\mathrm{CL}$ (e.g. that shown in Fig. 9). PAS-haematoxylin, $\times 642$.

Table 2. Reproductive condition of recently mated black mastiff bats with corpora lutea

\begin{tabular}{|c|c|c|c|c|c|c|}
\hline \multirow[b]{2}{*}{$\begin{array}{l}\text { Animal } \\
\text { no. }\end{array}$} & \multirow{2}{*}{$\begin{array}{c}\text { No. of } \\
\text { days after } \\
\text { introduction } \\
\text { of male }\end{array}$} & \multirow{2}{*}{$\begin{array}{l}\text { No. of } \\
\text { days of sperm } \\
\text { positive } \\
\text { smears }\end{array}$} & \multirow{2}{*}{$\begin{array}{l}\text { No. of } \\
\text { Graafian } \\
\text { follicles }\end{array}$} & \multicolumn{2}{|c|}{ No. of $\mathrm{CL}$} & \multirow[b]{2}{*}{ Endometrial condition } \\
\hline & & & & $\begin{array}{l}\text { Most } \\
\text { recent }\end{array}$ & Older & \\
\hline 59 & 9 & $5^{*}$ & 1 & $2 \dagger$ & - & $\begin{array}{l}\text { Proliferative; cellular debris in } \\
\text { lumen }\end{array}$ \\
\hline $40 \mathrm{~B}$ & 5 & 4 & - & 1 & - & $\begin{array}{l}\text { Endometrial necrosis and } \\
\text { sloughing (both horns); } \\
\text { decidual reaction in right horn }\end{array}$ \\
\hline $52 \mathrm{~B}$ & 5 & 4 & - & 1 & I & Decidual reaction (both horns) \\
\hline $54 \mathrm{~B}$ & 5 & 4 & 1 & 1 & - & $\begin{array}{l}\text { Shallow, proliferative; } \\
\text { abundant cellular debris in } \\
\text { lumen }\end{array}$ \\
\hline $57 \mathrm{~B}$ & 6 & 5 & 1 & 1 & - & Proliferative \\
\hline $58 \mathrm{~B}$ & 5 & 4 & - & 1 & 1 & Decidual reaction (both horns) \\
\hline $59 \mathrm{~B}$ & 6 & 5 & - & 1 & - & Decidual reaction (both horns) \\
\hline $60 \mathrm{~B}$ & 7 & 6 & - & 1 & 1 & Decidual reaction (both horns) \\
\hline $62 \mathrm{~B}$ & 7 & 6 & - & 1 & - & $\begin{array}{l}\text { Proliferative; cellular debris in } \\
\text { lumen }\end{array}$ \\
\hline $63 \mathrm{~B}$ & 7 & 6 & - & $1 t$ & 1 & Proliferative \\
\hline
\end{tabular}

*Bat had sperm-positive smears on Days 1, 3 and 7-9 after the introduction of the stud male.

+ Bat had 2 CL of same age.

$\ddagger$ Newly ruptured follicle; secondary oocyte in oviduct. 
(unpublished observations). The two remaining females had only older, regressing CL and involuted endometria.

Ten non-pregnant females which had been housed with stud males for 5-9 days also had recently formed CL and sometimes also older, regressing CL (Table 2; also Figs 2, 9, 10). Most of these females, killed between 30 January and 21 February, had fewer CL of different ages than did the June animals (Table 1). The general appearance of the reproductive tracts strongly suggested that, with the exception of the newly ruptured follicle present in 1 female, the CL had all been formed before the introduction of the males.

Many other bats examined in this study had only a single, recently formed CL or 2-3 such CL, all of the same age (Table 3). In non-pregnant animals the absence of older, regressing CL indicates that these bats had recently begun to ovulate. The extent to which this holds for the pregnant bats was less clear because of some uncertainty about the rate of involution of old CL during pregnancy and seasonal influences upon ovarian function. Old regressing $C L$ were observed in addition to the $C L$ of pregnancy in 4 females bearing well-developed fetuses (12 $1-24 \cdot 3 \mathrm{~mm}$ crown-rump length), but were not seen in 11 other bats carrying fetuses $>12.0 \mathrm{~mm}$. Most of these animals $(10 / 15)$ had, however, been inseminated early in the study (i.e. during December to February) and may have been pubertal or coming out of a seasonal anoestrous period at that time (see 'Discussion'). Many pregnant females $(22 / 31)$ bearing small conceptuses $(<12.0 \mathrm{~mm})$ also had only CL of pregnancy.

Table 3. Corpora lutea observed in black mastiff bats

\begin{tabular}{lcc}
\hline \multirow{2}{*}{$\begin{array}{l}\text { No. of corpora lutea } \\
\text { in right ovary }\end{array}$} & \multicolumn{2}{c}{ No. of bats } \\
\cline { 2 - 3 } & Pregnant & Non-pregnant \\
\hline None & - & 14 \\
1 & 28 & 12 \\
2 (same age) & 4 & 2 \\
2 (different ages) & 11 & 6 \\
3 (same age) & 1 & - \\
3 (different ages) & 1 & 3 \\
4 & - & $1^{*}$ \\
5 & $1 \dagger$ & $1_{+}^{+}$ \\
6 & - & $1 \S$ \\
\hline
\end{tabular}

*Bat had 2 new $C L$ and 2 older CL of different ages.

+ Bat had 2 new $C L$ of the same age and 3 older CL of the same age.

$\ddagger$ Bat had 1 new $C L$ and 2 pairs of older CL, each pair of a different age.

$\S$ Bat had 3 pairs of $C L$, each pair of a different age.

\section{Timing of ovulation and conception}

After the introduction of breeding males it was common to observe an extended period during which spermatozoa were present in the vaginal smears of the females (Fig. 12). The extent to which these spermatozoa came from reservoirs in the female tract, rather than from new ejaculations, has not been thoroughly defined. Evidence has been obtained, however, that female black mastiff bats do exhibit more than a limited period of oestrus (Rasweiler, 1987).

An effort was made in this study to determine how the prolonged presence of spermatozoa in the vaginal smears of these bats is related to the occurrence of ovulation and conception (Table 4). When females were examined within 12 days after the beginning of a period of sperm-positive smears at least 3 days long, 27/33 were found to be non-pregnant: of these 27, 15 had no large 
vesicular follicles or new CL present, 11 had large vesicular follicles present, and only 1 had a newly ruptured follicle present. Only $6 / 33$ bats had newly formed $C L$ and were pregnant. Most bats killed 14-30 days after the onset of such a smear pattern were pregnant (12/16 bats) or preovulatory with large, vesicular follicles (3/16 bats). Nearly all bats (28/29) killed on Days 32-94 were pregnant.

It would appear from an examination of the breeding records for bats killed during early pregnancy (Fig. 12) that most conceptions occurred during the extended period when spermatozoa were present in the smears. In 2 animals (Nos 50 and 66), however, the state of development of the embryos suggests that conception was associated with one of the sporadic matings observed before this period. Most of the bats (25/29) examined more than 1 month after the start of this period had more advanced conceptuses, i.e. $>6.0 \mathrm{~mm}$ crown rump length. One of the exceptional animals, killed 42 days after the onset of spermatozoa, in the vaginal smears, was not pregnant and lacked any CL. Two others examined on Days 36 and 40 carried, respectively, a somite-stage embryo (with a greatest length, measured in utero, of $1.4 \mathrm{~mm})$ and an early implanting blastocyst $(110 \times 140 \mu \mathrm{m})$. Since both of these animals had only CL of pregnancy, they had not been experiencing ovulatory cycles immediately before conception. The last bat, killed on Day 58, had an implanting primitive streak blastocyst $(1175 \times 1275 \mu \mathrm{m})$. This animal had 2 older $\mathrm{CL}$ of different ages in addition to the CL of pregnancy.

\section{Evidence of multiple ovulations}

Of the 72 bats with CL, 11 possessed 2 or more CL of the same histological age, suggesting that multiple ovulations had occurred. In one of these animals a degenerating ovum was observed in the uterus along with a morula. Two other non-pregnant females (Nos 46C and 50C; Table 1) each had a pair of recently-formed $C L$ and a pair of degenerating ova in the right horn of the uterus. The fate of the extra oocytes could not be determined in the remaining 8 females; however, in all of these considerable time had probably elapsed since formation of the CL.

Table 4. Ovarian condition of black mastiff bats examined within 1 month after the onset of a prolonged period of sperm-positive smears

\begin{tabular}{|c|c|c|c|c|}
\hline $\begin{array}{l}\text { Days after the onset } \\
\text { of a period* of } \\
\text { sperm-positive smears }\end{array}$ & $\begin{array}{l}\text { No. of bats } \\
\text { examined }\end{array}$ & $\begin{array}{c}\text { No. of bats } \\
\text { with a large } \\
\text { vesicular follicles }\end{array}$ & $\begin{array}{l}\text { No. of bats } \\
\text { with new CL } \dagger\end{array}$ & $\begin{array}{l}\text { No. of bats } \\
\text { with old CL }\end{array}$ \\
\hline 3 & 3 & 1 & - & 1 \\
\hline 4 & 7 & 2 & 1 & 4 \\
\hline 5 & 7 & 4 & - & 3 \\
\hline 6 & 7 & 2 & $2 \ddagger$ & 4 \\
\hline 8 & 3 & 1 & - & 1 \\
\hline 10 & 4 & - & $3 \S$ & - \\
\hline 12 & 2 & 1 & 1 & - \\
\hline 14 & 3 & - & $3 \S$ & - \\
\hline 16 & 2 & - & 2 & 2 \\
\hline 18 & 2 & 1 & 1 & 1 \\
\hline 20 & 2 & - & 2 & - \\
\hline 22 & 1 & - & 1 & - \\
\hline 24 & 1 & - & 1 & 1 \\
\hline 26 & 2 & $\cdots$ & 1 & - \\
\hline 28 & 1 & 1 & - & 1 \\
\hline 30 & 2 & 1 & 1 & - \\
\hline
\end{tabular}

*Duration of period at least 3 days.

†All bats with new CL were pregnant except for one animal examined on Day 6 which had a newly ruptured follicle.

† Includes 1 bat with a newly ruptured follicle.

$\S$ Includes 1 bat with an embryo probably conceived before the onset of the prolonged period of sperm-positive smears. 


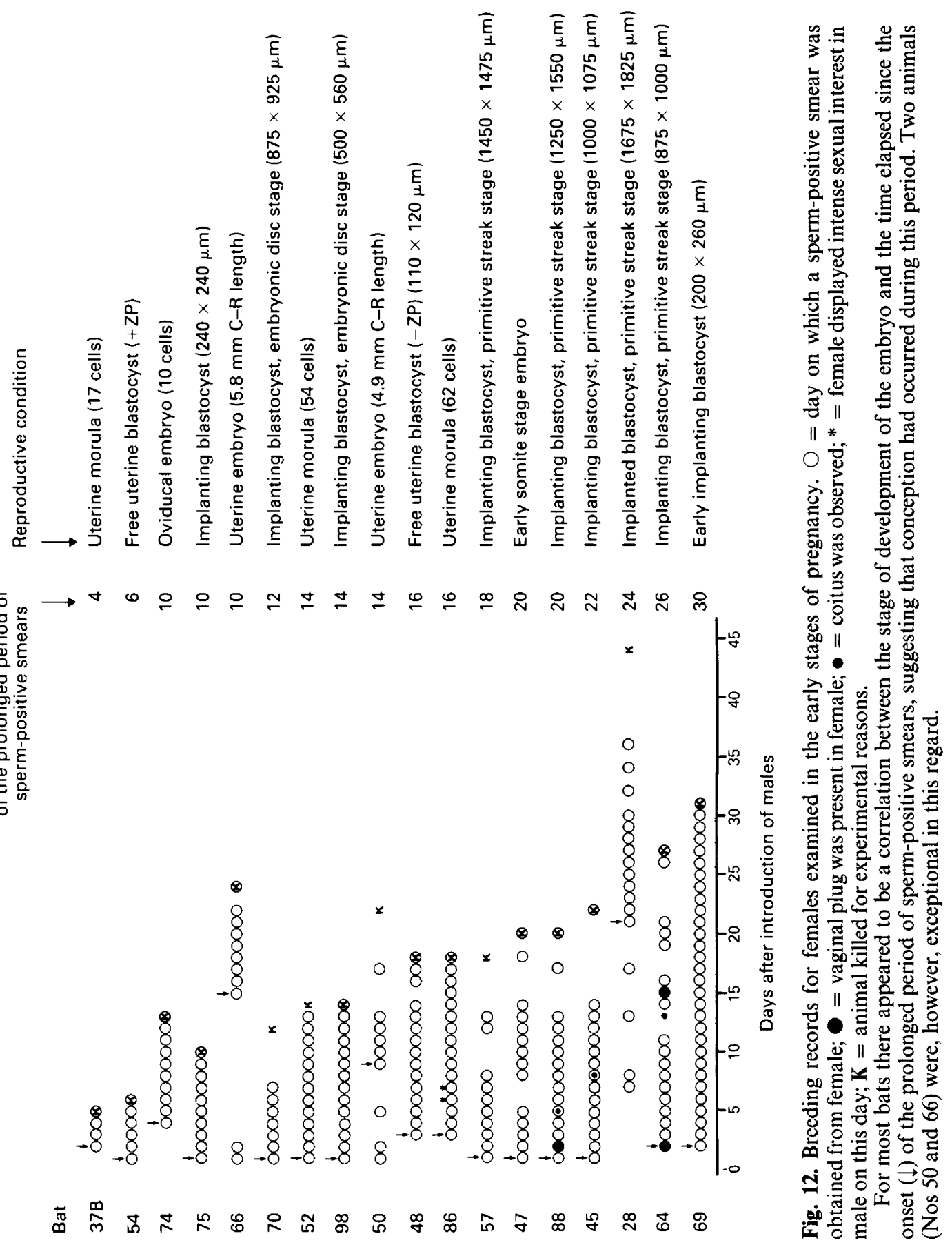



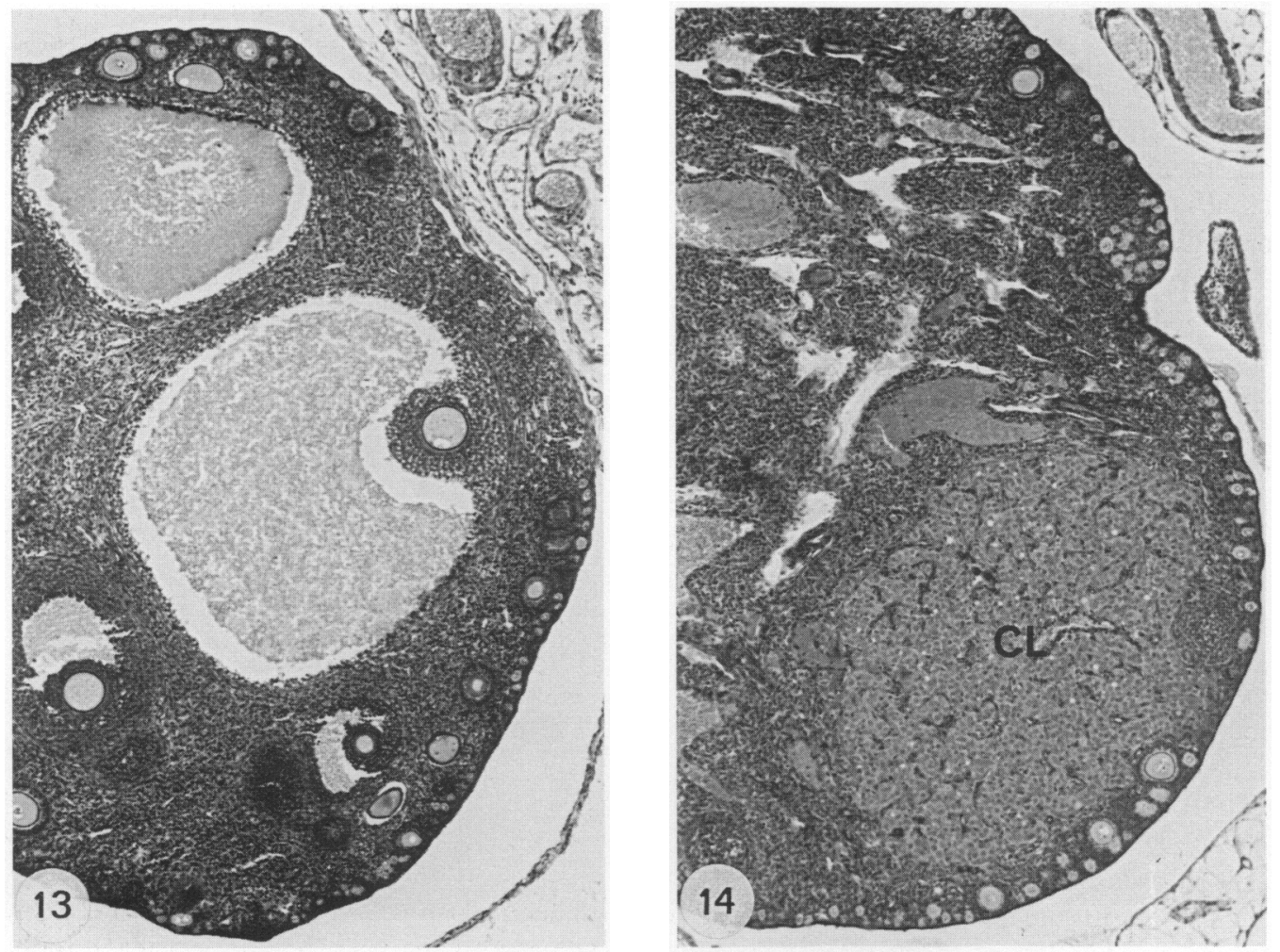

Figs 13 \& 14. Sections of the right ovary from a bat (No. 92) killed late in pregnancy (94 days after the initiation of a prolonged period of sperm-positive smears) and carrying a near-term fetus of $33.3 \mathrm{~mm}$ crown-rump length. This ovary had a healthy Graafian follicle with an oocyte at the germinal vesicle stage (Fig. 13), in addition to the CL of pregnancy (Fig. 14). PAShaematoxylin, $\times 64$.

\section{Ovaries of advanced pregnancy}

The ovaries of 7 females carrying advanced fetuses (22.6-34.8 mm crown-rump length) were examined. In each case the right ovary contained $1-3$ large $(312 \times 375-675 \times 675 \mu \mathrm{m})$, non-atretic, vesicular or Graafian follicles (Fig. 13) in addition to the CL of pregnancy (Fig. 14).

\section{Discussion}

This investigation has confirmed preliminary reports (Wimsatt, 1975, 1979) that the black mastiff bat exhibits complete dominance of the right ovary. Healthy preovulatory follicles and CL have been seen only in that ovary. Similar observations have also been made in nearly all other members of the bat family Molossidae so far examined (Sherman, 1937; Stephens, 1962; Kayanja \& Mutere, 1975; Wimsatt, 1975, 1979; Jerrett, 1978, 1979; Kitchener \& Hudson, 1982; Krutzsch \& Crichton, 1985; van der Merwe et al., 1986). However, an exception may be Tadarida midas in which fetuses have been found in the left uterine horn (Smithers, 1971).

The factors responsible for the poor development of follicles in the left ovary of many molossids are unclear. In almost all of the black mastiff bats that were examined in the present study the left 
ovary had a much less prominent intraovarian vascular supply than did the right ovary, even when large follicles and CL were absent from the latter. It would seem that this vascular difference, which presumably reflects the much smaller size of the left ovary, might limit the ability of follicles to grow on that side. Other investigators have also speculated that the functional asymmetry might be attributable to differences in the content of gonadotrophin receptors between the two ovaries (Krutzsch \& Crichton, 1985). Questions also remain as to the nature of the mechanisms that establish the differences in ovarian structure and responsiveness in the first place.

The California leaf-nosed bat (Macrotus californicus) and the mountain viscacha (Lagidium peruanum) also exhibit dominance of the right ovary, but following its removal ovulation will occur from the left ovary (Pearson, 1949; Bleier \& Ehteshami, 1981; Crichton \& Krutzsch, 1985). A similar response was not observed in Molossus sp. after removal of the right ovary (Wimsatt, 1979). Unfortunately, the details of these experiments have not been published, and it is unclear if the conditions were conducive to the occurrence of normal ovulations in control and sham-operated animals. Following removal of the dominant right ovary from another molossid bat, Tadarida brasiliensis mexicana, Jerrett (1978) noted some increase in weight of the left ovary in control and gonadotrophin-treated animals. No advanced follicular development or ovulations were subsequently observed on the left side, but these experiments were of relatively short duration.

Why it may be advantageous for the black mastiff bat and other molossids to exhibit functional dominance of one ovary remains open to speculation. Since relatively few follicles approach maturation in these animals, there would not seem to be much of a metabolic saving to be gained by reducing the folliculogenic function of the left ovary. On the other hand, interstitial gland tissue is a major component of both ovaries and clearly appears to be steroidogenic in other molossid bats (Kayanja \& Mutere, 1975; Jerrett, 1978, 1979). Possibly during the evolution of the molossid bats the ovarian stromal cells became committed to differentiate into interstitial gland tissue for physiological reasons that are still unclear, and this was balanced by the development of a small left ovary in order to limit the total amount of that tissue. The resultant reduced size and vascular supply of this ovary may then have been incompatible with normal folliculogenesis.

Evidence has been obtained in this study that the black mastiff bat is capable of ovulating spontaneously. Many of the females which were examined soon after the introduction of stud males already had CL, sometimes of several different ages. Furthermore, in many cases the most recent of the $\mathrm{CL}$ appeared to have been functional. These CL were associated with endometrial changes (e.g. decidual reactions and/or endometrial necrosis) that one might associate with the stimulation by, and in somes cases withdrawal of, luteal hormones.

Although these observations indicate that ovulation in the black mastiff bat can occur independently of coitus, they do not eliminate the possible involvement of male pheromones in stimulating ovarian activity. Throughout these studies male bats in breeding condition were housed in the same room with the females. Furthermore, the males have a cutaneous gland at the base of their throats that appears to play an important role in the bats' courtship behaviour (Rasweiler, 1987). In more recent efforts to breed some particularly tame stud males, these animals were frequently observed to extend their heads and to rub their gular glands on nearby females (unpublished observations). The precise function of this activity remains to be elucidated.

The question remains as to why more of the females did not have old CL from previous, non-fertile cycles. The available information on seasonal breeding in the wild population suggests that the animals lacking old CL may have been pubertal or coming out of a seasonal or lactational anoestrous period. All of the bats examined in this study were killed between January and June of the year after capture. Some of the animals which had been captured during July and August were pregnant, but none of those taken in November were. Furthermore, some of the bats captured during November were obviously juveniles. Other investigators have taken pregnant black mastiff bats between March and October on Trinidad, lactating females between July and October, and immature animals between July and November (Greenhall \& Stell, 1960; Goodwin \& Greenhall, 1961). 
Unfortunately, the examination of daily vaginal smears for spermatozoa did not provide a precise method for timing ovulation and conception in the black mastiff bats, since the females were receptive to the males at least periodically over extended intervals and at times other than immediately around ovulation (Rasweiler, 1987). Nevertheless, there did appear to be a correlation between the onset of a prolonged period of sperm-positive smears and the occurrence of ovulation and conception. Females examined within the first 12 days after the onset of such a period were very likely to be preovulatory or to lack both large vesicular follicles and new CL. However, some of these animals were killed after only a short period of sperm-positive smears which might not have persisted and been followed soon by ovulation. Animals examined after Day 12 were usually pregnant and in progressively more advanced stages of pregnancy as the length of time from the onset of the sperm-positive period increased. There were, however, a few exceptional animals which ovulated either very soon or quite a long time after the start of this period.

The relatively high incidence of multiple ovulations from the right ovary was a surprise in view of the lack of ovulations from the left ovary and since twinning has never been observed in black mastiff bats. Such multiple ovulations may persist in a significant proportion of the bat population, since they would provide extra eggs to compensate for occasional failures of fertilization or early embryonic development. This could be especially advantageous for a seasonal breeder with a low reproductive potential. On the other hand, it seems rather unlikely that the establishment of a multiple pregnancy would lead to serious complications. The blastocysts of this bat expand considerably after entering the uterus and implant superficially (see Fig. 5 in Rasweiler, 1987). This may exclude any extra blastocysts from the cranial end of the right uterine horn, which appears to be the only site where a chorioallantoic placenta can be formed (unpublished observations), and thereby preclude advanced development of those conceptuses.

The presence of Graafian follicles in the ovaries of females in advanced pregnancy suggests that the black mastiff bat may ovulate again after parturition. Krutzsch \& Crichton (1985) obtained evidence that this may also hold for Molossus fortis which appears to have two synchronized pregnancy periods in quick succession in the wild. Graafian follicles were noted in pregnant and lactating $M$. fortis taken at what seemed to be the end of the first of these periods.

I thank members, particularly Mr P. Deoraj and Professor J. S. Kenny, of the Department of Zoology at the University of the West Indies in St Augustine, Trinidad, for generous assistance and the use of departmental facilities during the course of the field work required for this study; and Mrs Pilar Castañeda for technical assistance. This work was supported by Grants HD-17739 and RR-05396 from the National Institutes of Health.

\section{References}

Bleier, W.J. \& Ehteshami, M. (1981) Ovulation following unilateral ovariectomy in the California leaf-nosed bat (Macrotus californicus). J. Reprod. Fert. 63, 181-183.

Crichton, E.G. \& Krutzsch, P.H. (1985) Reproductive biology of the female leaf-nosed bat, Macrotus californicus, in southwestern United States: I. A morphometric analysis of the annual ovarian cycle. Am. $J$. Anat. 173, 69-87

Goodwin, G.G. \& Greenhall, A.M. (1961) A review of the bats of Trinidad and Tobago. Bull. Am. Mus. Nat. Hist. 122, 187-302.

Greenhall, A.M. \& Stell, G. (1960) Bionomics and chemical control of free-tailed house bats (Molossus) in Trinidad. Special Scientific Report: Wildlife No.
53, 1-20. U.S. Dept. Interior, Fish \& Wildlife Service, Washington, D.C.

Jerrett, D.P. (1978) Unilateral ovulation in the Mexican free-tailed bat, Tadarida brasiliensis mexicana. Ph.D. thesis, University of Arizona, Tucson.

Jerrett, D.P. (1979) Female reproductive patterns in non-hibernating bats. J. Reprod. Fert. 56, 369-378.

Kayanja, F.I.B. \& Mutere, F.A. (1975) The ovary of the insectivorous bat Otomops martiensseni. Anat. Anz. 137, 166-175.

Kitchener, D.J. \& Hudson, C.J. (1982) Reproduction in the female white-striped mastiff bat, Tadarida australis (Gray) (Molossidae). Aust. J. Zool. 30, 1-14.

Krutzsch, P.H. \& Crichton, E.G. (1985) Observations on the reproductive cycle of female Molossus fortis 
(Chiroptera: Molossidae) in Puerto Rico. J. Zool., Lond. 207, 137-150.

Pearson, O. P. (1949) Reproduction of a South American rodent, the mountain viscacha. Am. J. Anat. 84, 143-171.

Rasweiler, J.J., IV (1987) Prolonged receptivity to the male and the fate of spermatozoa in the female black mastiff bat, Molossus ater. J. Reprod. Fert. 79, 643-654.

Sherman, H.B. (1937) Breeding habits of the free-tailed bat. J. Mammal. 18, 176-187.

Smithers, R.H.N. (1971) The Mammals of Botswana, Museum Memoir No. 4. Trustees of the National Museums of Rhodesia, Salisbury.

Stephens, R.J. (1962) Histology and histochemistry of the placenta and fetal membranes in the bat, Tadarida brasiliensis cynocephala (with notes on maintaining pregnant bats in captivity). Am.J. Anat. 111, 259-286. van der Merwe, M., Rautenbach, I.L. \& van der Colf, W.J. (1986) Reproduction in females of the little free-tailed bat, Tadarida (Chaerophon) pumila, in the eastern Transvaal, South Africa. J. Reprod. Fert. 77, 355-364.

Wimsatt, W.A. (1975) Some comparative aspects of implantation. Biol. Reprod. 12, 1-40.

Wimsatt, W.A. (1979) Reproductive asymmetry and unilateral pregnancy in Chiroptera. J. Reprod. Fert. 56, 345-357.

Received 17 March 1987 